Malin Olofsson*, Anders Torstensson, Maria Karlberg, Franciska S. Steinhoff, Julie Dinasquet, Lasse Riemann, Melissa Chierici and Angela Wulff

\title{
Limited response of a spring bloom community inoculated with filamentous cyanobacteria to elevated temperature and $p \mathrm{CO}_{2}$
}

https://doi.org/10.1515/bot-2018-0005

Received 25 January, 2018; accepted 2 October, 2018; online first 9 November, 2018

Abstract: Temperature and $\mathrm{CO}_{2}$ levels are projected to increase in the future, with consequences for carbon and nutrient cycling in brackish environments, such as the Baltic Sea. Moreover, filamentous cyanobacteria are predicted to be favored over other phytoplankton groups under these conditions. Under a 12-day outdoor experiment, we examined the effect on a natural phytoplankton spring bloom community of elevated temperature (from $1^{\circ} \mathrm{C}$ to $4^{\circ} \mathrm{C}$ ) and elevated $p \mathrm{CO}_{2}$ (from 390 to $970 \mu \mathrm{atm}$ ). No effects of elevated $p \mathrm{CO}_{2}$ or temperature were observed on phytoplankton biovolumes, but a significantly higher photosystem II activity was observed at elevated temperature after 9 days. In addition, three species of diazotrophic filamentous cyanobacteria were inoculated to test their competitive capacity under spring bloom conditions. The toxic cyanobacterium Nodularia spumigena exhibited an average specific growth rate of $0.10 \mathrm{~d}^{-1}$ by the end of the experiment, indicating potential prevalence even during wintertime in the Baltic Sea. Generally, none of the inoculated cyanobacteria species were able to outcompete the natural phytoplankton species at temperatures $\leq 4^{\circ} \mathrm{C}$. No direct effects were found on heterotrophic bacteria. This study demonstrates the highly efficient resistance towards

*Corresponding author: Malin Olofsson, University of Gothenburg, Department of Marine Sciences, Box 461, Gothenburg SE-405 30, Sweden, e-mail: malin.olofsson@marine.gu.se

Anders Torstensson, Maria Karlberg, Franciska S. Steinhoff and Angela Wulff: University of Gothenburg, Department of Biological and Environmental Sciences, Box 461, Gothenburg SE-405 30, Sweden

Julie Dinasquet: Scripps Institution of Oceanography, UC San Diego, 9500 Gilman Drive, La Jolla, CA 92093 0202, USA; and University of Copenhagen, Marine Biological Section, Department of Biology, Strandpromenaden 5, Helsingør DK-3000, Denmark Lasse Riemann: University of Copenhagen, Marine Biological Section, Department of Biology, Strandpromenaden 5, Helsingør DK-3000, Denmark

Melissa Chierici: Institute of Marine Research, Fram Centre, 9007, Tromsø, Norway short-term (12 days) changes in abiotic factors by the natural Baltic Sea spring bloom community.

Keywords: Baltic Sea; carbon dioxide; climate change; diatoms; Nodularia spumigena.

\section{Introduction}

The Baltic Sea covers an area of $377,000 \mathrm{~km}^{2}$ and is the second largest brackish sea on Earth. Due to climate change, the temperature of the Baltic Sea is predicted to increase by $2-5^{\circ} \mathrm{C}$ over the coming 100 years (HELCOM 2013), while the global atmospheric partial pressure of $\mathrm{CO}_{2}\left(p \mathrm{CO}_{2}\right)$ will rise from current values of ca. $400 \mu$ atm (National Oceanic and Atmospheric Administration, U.S. Department of Commerce, for December 2017) to >970 $\mu$ atm (IPCC 2013). Uptake of anthropogenic $\mathrm{CO}_{2}$ is causing changes in the marine carbonate system and will result in a $\mathrm{CO}_{2}$-enriched and more acidic state, and a concomitant elevated temperature may alter the biogenic carbon flow. In particular, in areas of high productivity and with temperatures $<20^{\circ} \mathrm{C}$ (Wohlers et al. 2009), increased temperatures may result in higher respiration rates and decreased net productivity rates. These changes are predicted to affect all trophic levels of the planktonic food web, and thereby nutrient and carbon cycling in areas such as the Baltic Sea (Andersson et al. 2015).

Phytoplankton have flexible strategies to cope with environmental heterogeneities, e.g. changes in light conditions and nutrient supply (Boyd et al. 2016). Baltic Sea phytoplankton communities experience large daily variation in $\mathrm{pH}$, e.g. ranging from early morning values of 7.8-8.4 in the afternoon during a summer bloom (Wulff et al. 2018), similar to $\mathrm{pH}$ ranges measured in natural aggregates of filamentous cyanobacteria (Ploug 2008). Hence, natural phytoplankton thrive despite large fluctuations in $\mathrm{pH}$ and $p \mathrm{CO}_{2}$. Diatoms and dinoflagellates usually dominate the spring bloom (March-May) in the Baltic Proper (Andersson et al. 1994, Wasmund et al. 1998, Groetsch et al. 2016). Thereafter, $\mathrm{N}_{2}$-fixing cyanobacteria like Aphanizomenon sp. (A. Morren ex É. Bornet and C. Flauhault 1886 '1888'), Nodularia spumigena (Mertens ex Bornet and Flauhault 1888) 
and Dolichospermum spp. ((Ralfs ex Bornet and Flauhault) P. Wacklin, L. Hoffmann and J. Komárek 2009) (Larsson et al. 2001) proliferate and contribute with a large input of fixed $\mathrm{N}_{2}$ to the system (Klawonn et al. 2016) and act as a local supply of $\mathrm{NH}_{4}^{+}$to surrounding organisms (Ploug et al. 2011). Aphanizomenon sp. and $N$. spumigena may be observed in low concentrations all year round (Suikkanen et al. 2010, Wasmund 2017), with high rates of $\mathrm{N}_{2}$-fixation by Aphanizomenon spp. down to $10^{\circ} \mathrm{C}$ (Svedén et al. 2015). Whether $\mathrm{N}_{2}$-fixation is carried out at even lower temperatures in the Baltic Sea remains unknown, but expression of nitrogenase genes has been observed locally (Bentzon-Tilia et al. 2015) and in the Arctic (Blais et al. 2012) at temperatures close to freezing. Also, potentially toxic filamentous cyanobacteria formed winter blooms in a temperate lake system at $3^{\circ} \mathrm{C}$ (Wejnerowski et al. 2018). A satellite-data based study of surface temperature predicts an earlier start of the summer season in the Baltic Sea (Kahru et al. 2016), with an earlier initiation of the spring bloom (Sommer et al. 2012). This may also induce an earlier and more extensive cyanobacterial summer bloom, as warmer temperatures are predicted to favor various groups of cyanobacteria $(\mathrm{Fu}$ et al. 2007, Paerl and Huisman 2008, Davis et al. 2009, Karlberg and Wulff 2013).

The multitude of environmental factors and complex interactions between trophic levels affected by climate change hamper qualified predictions on the future biomass and composition of phytoplankton in the Baltic Sea Proper, and on the success of various cyanobacterial groups. To start disentangling these complex interactions, we performed a bi-factorial experiment with a microplanktonic Baltic Sea community and inoculated strains of key diazotrophic filamentous cyanobacteria. Hereby, we aimed to (1) test the resistance of a natural spring bloom community, in terms of biovolume and species composition, to increased temperature and elevated $p \mathrm{CO}_{2}$, and (2) test the potential of diazotrophic filamentous cyanobacteria to compete with the natural spring bloom community under predicted future conditions.

\section{Materials and methods}

\section{Experimental setup and sampling procedure}

The outdoor experiment was conducted between 23 March and 4 April 2011. The water was collected at the Baltic Sea Proper monitoring station B1 on 17 March $2011\left(58^{\circ} 49^{\prime} \mathrm{N}\right.$, $17^{\circ} 38^{\prime} \mathrm{E}$ ), with a salinity of 6.6 and a sea surface temperature of ca. $1^{\circ} \mathrm{C}$. The collected water was gently sieved through a $200-\mu \mathrm{m}$ mesh to exclude large grazers. Cultures of the following diazotrophic filamentous cyanobacterial strains were obtained from the Kalmar Algae Collection, Linnaeus University, Kalmar, Sweden: Aphanizomenon sp. (A. Morren ex É. Bornet and C. Flauhault 1886, 1888'), Nodularia spumigena (Mertens ex Bornet and Flauhault 1888) and Dolichospermum spp. ((Ralfs ex Bornet and Flauhault) P. Wacklin, L. Hoffmann and J. Komárek 2009) (KAC16, formerly known as Anabaena sp.), isolated from the Baltic Sea and kept at $10^{\circ} \mathrm{C}$, were inoculated into the natural community. The cyanobacteria were pre-cultured for 1 week under nutrient replete conditions, $6^{\circ} \mathrm{C}$ and ca. $20 \mu \mathrm{mol}$ photons $\mathrm{m}^{-2} \mathrm{~s}^{-1}$. The proportion of inoculated cyanobacteria to the natural community was based on in situ conditions at the nearby monitoring station B1 in June with a ratio of 1:10 between cyanobacteria and diatoms + dinoflagellates (from the database of the Swedish Meteorological and Hydrological Institute, for June 2011), hereby adding ca. $0.1 \mathrm{~mm}^{3} \mathrm{l}^{-1}$ of the three cyanobacteria species all together. Biovolume $\left(\mathrm{mm}^{3} \mathrm{l}^{-1}\right)$ is recommended by HELCOM as a proxy for Baltic Sea phytoplankton biomass (Olenina et al. 2006).

After filtration and inoculation, the water was divided into $12 \times 4-1$ Plexiglas aquaria. Triplicates of four treatments were established by combining ambient temperature $\left(1^{\circ} \mathrm{C}\right)$ and elevated temperature $\left(4^{\circ} \mathrm{C}\right)$ with ambient $p \mathrm{CO}_{2}(390$ $\mu \mathrm{atm})$ and elevated $p \mathrm{CO}_{2}(970 \mu \mathrm{atm})$ in an orthogonal design. The elevated temperature and $\mathrm{CO}_{2}$ levels are according to the predictions by HELCOM (2013) and IPCC (2013) for the coming 100 years. The aquaria were randomly placed in two temperature controlled water baths, recorded with two loggers per basin (HOBO Pendant, Onset Computer Corporation, USA). The basins were exposed to sunlight and covered with green plastic mesh to reduce direct solar irradiance including ultraviolet radiation, mimicking photosynthetically active radiation (PAR, 400-700 nm) at $1 \mathrm{~m}$ water depth at station B1. PAR was measured with a LI-1000 datalogger equipped with a Li-Cor UWQ5201 PAR sensor (Li-COR, Lincoln, USA). A Li-COR radiometer equipped with a $2 \pi$ PAR sensor was used to record irradiances under the mesh throughout the experiment.

The two $\mathrm{pCO}_{2}$ treatments were established by connecting each aquarium with a tube, constantly providing synthetic air (AGA Gas, Linköping, Sweden). The gas was dispersed to the water by plastic air diffusers at a flow rate of $\sim 15 \mathrm{ml} \mathrm{min}^{-1}$. The aquaria were sealed with Plexiglas lids, where small holes were maintained for gas outlet to prevent backpressure build-up. In addition, each aquarium was provided with a submerged tube connected to an external syringe, which was used to transfer subsamples from the aquaria without opening the lids and thus disturbing the $p \mathrm{CO}_{2}$ of the headspace $($ ca. $5 \mathrm{~cm}$ ). 
Each of the aquaria were subsampled for phytoplankton growth and species composition, bacterial abundance and production, dissolved inorganic nutrients, and carbonate system parameters at around $08: 00 \mathrm{~h}$ on days 0,3 , 6, 9 and 12. On days 0 and 12, samples for photosynthetic pigment analysis and stoichiometry were collected. After analysis of in situ conditions, additional $\mathrm{PO}_{4}^{3-}$ of ca. $4 \mu \mathrm{M}$ of was added at day 1 to avoid limitation. For each of the four treatments, one additional aquarium containing only 0.2- $\mu \mathrm{m}$ filtered seawater was sampled for $\mathrm{pH}$, total alkalinity, temperature and inorganic nutrients, to control for non-organismal effects on the carbonate system.

\section{Determination of the carbonate system}

Total alkalinity $\left(\mathrm{A}_{\mathrm{T}}\right)$ and $\mathrm{pH}$ were established according to Dickson et al. (2007). Samples for $\mathrm{pH}$ determination were 0.2- $\mu \mathrm{m}$ filtered and analyzed spectrophotometrically (Shimadzu UV-2100) at $19.0^{\circ} \mathrm{C}$ on the total scale $\left(\mathrm{pH}_{\mathrm{T}}\right)$, using a 2-mM solution of $\mathrm{m}$-cresol purple as indicator (Clayton et al. 1995). The $\mathrm{pH}$ of the indicator solution was measured and the perturbation of the sample $\mathrm{pH}$ by the addition of indicator was corrected according to Chierici et al. (1999).

$\mathrm{A}_{\mathrm{T}}$ was determined using a potentiometric titration with $0.05 \mathrm{M} \mathrm{HCl}$ (Haraldsson et al. 1997). The equivalence point was estimated using Gran evaluation (Gran 1952) and manual titration with a dosimat (876 Dosimat plus, Metrohm) and a pH sensitive electrode (Aquatrode with Pt1000 Thermistor, Metrohm). The accuracy was tested using certified reference material (CRM) batch 97 supplied by A. Dickson, San Diego, USA (Dickson et al. 2007), with an average value of $2206 \pm 5.3 \mu \mathrm{mol} \mathrm{kg}{ }^{-1}$.

Calculations of $p \mathrm{CO}_{2},\left[\mathrm{HCO}_{3}{ }^{-}\right],\left[\mathrm{CO}_{3}{ }^{2-}\right]$ and $\left[\mathrm{CO}_{2}\right]$ were performed with the chemical speciation model CO2SYS (Pierrot et al. 2006). Measured data for $\mathrm{pH}$ at $19.0^{\circ} \mathrm{C}, \mathrm{A}_{\mathrm{T}}$, $\left[\mathrm{PO}_{4}\right],\left[\mathrm{Si}(\mathrm{OH})_{4}\right]$, salinity, and temperature were used in the calculation together with the constant for $\mathrm{HSO}_{4}{ }^{-}$determined by Dickson (1990) and the total hydrogen ion scale $\left(\mathrm{pH}_{\mathrm{T}}\right)$. The dissociation constants used for carbonic acid $\left(\mathrm{K}_{1}\right.$ and $\mathrm{K}_{2}$ ) were determined as described by Mehrbach et al. (1973) and refitted by Dickson and Millero (1987).

\section{Stoichiometry and analyses of dissolved inorganic nutrients}

To determine the concentration of particulate organic carbon (POC) and nitrogen (particulate organic nitrogen, PON), 150-ml samples were filtered onto pre-combusted $\left(400^{\circ} \mathrm{C}, 4 \mathrm{~h}\right) \mathrm{GF} / \mathrm{C}$ filters $(25 \mathrm{~mm})$. The filters were frozen at $-20^{\circ} \mathrm{C}$, freeze-dried, ground (MM301, Retsch, Haan, Germany), and analyzed on an EA 1108 (CHNS-O, Fisons Instruments, Thermo Fisher Scientific, Waltham, MA, USA) applying 2,5-bis-[5-ert.-butyl-bensoaxzol-2-yl]thiophen as standard. To determine the concentration of dissolved inorganic $\mathrm{NO}_{3}^{-}+\mathrm{NO}_{2}^{-}$(dissolved inorganic nitrogen, DIN), $\mathrm{PO}_{4}^{3-}$ (dissolved inorganic phosphorus, DIP) and $\mathrm{Si}$ (dissolved inorganic silicate, DISi), $20 \mathrm{ml}$ of sample was filtered through a $0.2-\mu \mathrm{m}$ pore-size filter and stored at $-80^{\circ} \mathrm{C}$, until analyzed within 3 weeks on an autoanalyzer (Grasshoff et al. 1999).

\section{Photosynthetic activity}

Photosynthetic activity was estimated by variable chlorophyll fluorescence measurements in photosystem II (PSII), with a WATER-PAM (Pulse amplitude modulated fluorometer) equipped with red light emitting diodes (Walz Mess- und Regeltechnik, Effeltrich, Germany). Samples were dark adapted at in situ temperature for a minimum of $20 \mathrm{~min}$ before measurements. Minimum fluorescence $\left(\mathrm{F}_{0}{ }^{\prime}\right)$ was determined by applying a low level of light and the maximum fluorescence $\left(\mathrm{F}_{\mathrm{m}}{ }^{\prime}\right)$ by exposing the sample to a short saturation pulse of light $(>4000 \mu \mathrm{mol}$ photons $\mathrm{m}^{-2} \mathrm{~s}^{-1}$ for $\left.0.6 \mathrm{~s}\right)$. Variable fluorescence $\left(\mathrm{F}_{\mathrm{v}}=\mathrm{F}_{\mathrm{m}}{ }^{\prime}-\mathrm{F}_{0}{ }^{\prime}\right)$ and maximum quantum yield $\left(\mathrm{F}_{\mathrm{v}} / \mathrm{F}_{\mathrm{m}}\right)$ were determined for all samples. Rapid light curves (RLCs) were performed by measurement of $\Delta \mathrm{F} / \mathrm{F}_{\mathrm{m}}{ }^{\prime}\left(\left(\mathrm{F}_{\mathrm{m}}{ }^{\prime}-\mathrm{F}_{0}\right) / \mathrm{F}_{\mathrm{m}}{ }^{\prime}\right)$ of quasi-adapted (15 s) cells at nine levels of actinic light $(0,51,76,110,165$, $250,368,571$ and $851 \mu \mathrm{mol}$ photons $\left.\mathrm{m}^{-2} \mathrm{~s}^{-1}\right)$ in the emitterdetector unit. Relative electron transport rate (rETR) was calculated by effective quantum yield $\left(\Delta \mathrm{F} / \mathrm{F}_{\mathrm{m}}{ }^{\prime}\right)$ multiplied by PAR irradiance. Photosynthetic parameters $\left(\mathrm{rETR}_{\max }\right.$, $\mathrm{E}_{\mathrm{k}}$, and $\left.\alpha_{\mathrm{PSII}}\right)$ were calculated according to Jassby and Platt (1976), fitted by the Nelder-Mead method in the R package phytotools (Silsbe and Malkin 2015, R Core Team 2016).

\section{Microplanktonic composition and specific growth rates}

Samples (50 ml) were preserved with alkaline Lugol's solution, stored in darkness, and analyzed within 3 months using the Utermöhl method according to HELCOM (2014a). Half of the chamber was viewed at 100× magnification (Zeiss Axiovert 40CFL, Germany) and organisms $>30 \mu \mathrm{m}$ were counted and identified to species level or group (e.g. pennate diatom). Lengths and widths were measured and biovolume $\left(\mathrm{mm}^{3} \mathrm{l}^{-1}\right)$ was calculated according to Hillebrand et al. (1999). At 200× and 400× magnification, a 
transect diagonally across the chamber bottom (1000 and $500 \mu \mathrm{m}$ wide, respectively) was analyzed and organisms $>8 \mu \mathrm{m}$ were counted. The biovolume $\left(\mathrm{mm}^{3} \mathrm{l}^{-1}\right)$ of organisms $>8 \mu \mathrm{m}$ was thereafter converted into POC based on Menden-Deuer and Lessard (2000). The calculated POC based on microscopy analysis was compared to the measured POC analyzed on GF/C filters, in order to estimate the fraction of organisms or organic material not identifiable by microscopy (ca. 1-8 $\mu \mathrm{m})$. Specific growth rate was calculated for diatoms, dinoflagellates, and each cyanobacterial species separately, for days $6-12$. The specific growth rate $\left(\mu \mathrm{d}^{-1}\right)=(\ln D B-\ln D A) /(t \mathrm{~B}-t \mathrm{~A})$, where $D \mathrm{~A}$ is the biovolume $\left(\mathrm{mm}^{3} \mathrm{l}^{-1}\right)$ at the first day of a period and $D B$ the biovolume at the end of the period, and $t \mathrm{~A}$ is day $\mathrm{A}$ and $t \mathrm{~B}$ is day $\mathrm{B}$.

\section{Heterotrophic bacterial abundance and productivity}

$1.5 \mathrm{ml}$ of sample were fixed with $1 \%$ glutaraldehyde and stored at $-80^{\circ} \mathrm{C}$. The samples were thawed, stained with SybrGreen (Invitrogen) and counted on a FASCanto II flow cytometer (Becton Dickinson; Gasol and del Giorgio 2000) using fluorescent beads (True counts, Becton Dickinson) to calibrate the flow rate. Bacterial productivity was measured by [ $\left.{ }^{3} \mathrm{H}\right]$-thymidine incorporation (Fuhrman and Azam 1982) as modified for microcentrifugation by Smith and Azam (1992). Duplicate $1.7 \mathrm{ml}$ aliquots were incubated with [methyl ${ }^{3} \mathrm{H}$ ]-thymidine (20 nM final conc., GE Healthcare) in sterile 2.0-ml capacity polypropylene tubes for ca. $1 \mathrm{~h}$ at in situ temperature. Duplicate blanks (killed control) were prepared by adding 5\% trichloracetic acid prior to the addition of isotopes. Productivity was calculated using $1.4 \times 10^{18}$ cells mole $^{-1}$ thymidine incorporated (average calculated from published Baltic Sea data, $\mathrm{SE}=0.1 \times 10^{18}$ cells mole $^{-1}$ thymidine, $\mathrm{n}=73$; HELCOM 2014b) and $20 \mathrm{fg}$ carbon cell $^{-1}$ (Lee and Fuhrman 1987).

\section{Statistical analyses}

All data were analyzed for effects of elevated $p \mathrm{CO}_{2}$ and temperature by linear mixed effects (LME) modeling using the package nlme in R (R Core Team 2016, Pinheiro et al. 2017). All models were fitted using restricted maximum likelihood, where sampling day was included as a fixed, categorical factor, and aquarium was included as a random factor (random intercept) to account for repeated measurement over time. Response variables were biovolume of the cyanobacterial species, diatoms, dinoflagellates, ciliates,
POC, PON, heterotrophic bacterial abundance and productivity and photosynthetic activity $\left(\mathrm{F}_{\mathrm{v}} / \mathrm{F}_{\mathrm{m}}, \mathrm{rETR}_{\max }, \mathrm{E}_{\mathrm{k}}\right.$, and $\alpha_{\text {PSII }}$ ). Multiple comparisons of significant factors were performed by Tukey's HSD test using the lsmeans package (Lenth 2016) in R. Parametric assumptions were visually verified using boxplots and Q-Q plots (Quinn and Keough 2002) and, if necessary, data were either log (POC, PON and POC:PON) or square root [cell-specific bacterial productivity (CSP), EETR $_{\text {max }}, E_{k}$ ] transformed. In addition, regression analysis was performed between bacterial abundance and biovolume of phytoplankton groups, POC:PON, POC and PON, using Pearson correlation for day 12 (SPSS). Significance was set to $\mathrm{p}<0.05$. Additional multivariate analyses were performed to detect differences between treatments or time on species level and are included as Supplementary material.

\section{Results}

In summary, a significantly higher $\mathrm{F}_{\mathrm{v}} / \mathrm{F}_{\mathrm{m}}$ value was found at elevated temperatures at days 9 and 12, as compared to ambient conditions. For bacterial abundance, interaction effects between temperature and $p \mathrm{CO}_{2}$ were found at day 12, and a higher POC:PON ratio at elevated temperatures as compared to ambient. No treatment effects on the biovolume of diatoms, dinoflagellates or filamentous cyanobacteria were observed. The results are presented in detail below.

\section{Temperature and the carbonate system}

As desired, our manipulation generated ambient and elevated temperature conditions from day 1 onwards (Figure 1A). The average $\mathrm{pH}$ was 7.70 in all treatments at day 0 (before starting the $p \mathrm{CO}_{2}$ treatment), thereafter the elevated $p \mathrm{CO}_{2}$ remained ca. $0.2 \mathrm{pH}$ units below ambient $\mathrm{pCO}_{2}$ (Table 1). The average total alkalinity $\left(\mathrm{A}_{\mathrm{T}}\right)$ was $1527 \mu \mathrm{mol} \mathrm{kg}{ }^{-1}$ at day 0 , and 1573 at day 12, with no difference between the treatments (Table 1). The $p \mathrm{CO}_{2}$ at day 12 was lower in the treatments with organisms as compared to the controls without organisms.

\section{Stoichiometry and dissolved inorganic nutrients}

There was a significant interaction between sampling day and temperature for POC and PON concentration 

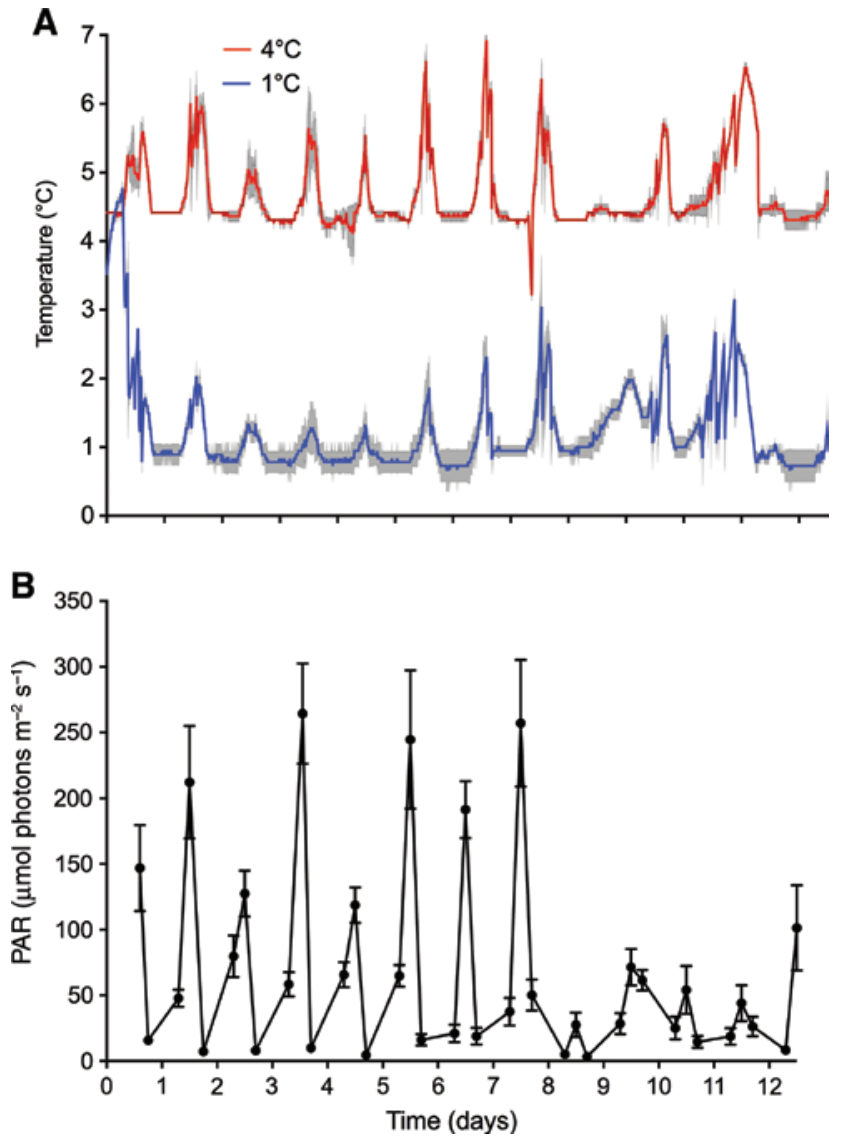

Figure 1: Environmental conditions during the experiment. (A) Temperature $\left({ }^{\circ} \mathrm{C}\right.$ ) at ambient (blue: $1^{\circ} \mathrm{C}$ ) and elevated (red: $4^{\circ} \mathrm{C}$ ) conditions. (B) Radiation conditions (PAR, 400-700 nm) during the experiment. Gray areas (A) and error bars (B) indicate standard deviation, $\mathrm{n}=2$.

$\left[\mathrm{p}=0.006\right.$ and $0.002, \mathrm{~F}_{1,8}=13.9$ and 16.6 , respectively, linear mixed effects (LME)]. The concentrations of POC and PON (Table 2) did not differ between temperatures at day 0 ( $\mathrm{p}>0.132$, Tukey's test), but were significantly higher at ambient temperature as compared to elevated temperature at day $12(\mathrm{p}=0.010$ and $\mathrm{p}<0.0001$, respectively, Tukey's test). The measured POC $(>1 \mu \mathrm{m})$ was ca. 20-40 times higher than the calculated POC based on microscopy ( $>8 \mu \mathrm{m}$ ) analysis at day 0 , and ca. 46-128 times higher at day 12 (Table 2). There was a significant interaction between sampling day and $p \mathrm{CO}_{2}$ for the POC:PON ratio $\left(\mathrm{p}<0.018, \mathrm{~F}_{1,8}=8.9\right.$, LME). Thus, the interaction between sampling day and $p \mathrm{CO}_{2}$ was reflected by a significant difference between $p \mathrm{CO}_{2}$ treatments for POC:PON ratio at day $0(p=0.005$, Tukey's test), but no difference at day 12 ( $\mathrm{p}=0.999$, Tukey's test). Also, the POC:PON ratio was, overall, significantly higher at elevated temperature than at ambient temperature $\left(\mathrm{p}=0.002, \mathrm{~F}_{1,8}=21.0\right.$, LME, Table 2).
The concentration of DIN $\left(\mathrm{NO}_{3}^{-}+\mathrm{NO}_{2}^{-}\right)$was around $8 \mu \mathrm{M}$ at day 0 and decreased to below the detection limit $(<0.2 \mu \mathrm{M})$ at elevated temperatures at day 3 , but with a concentration $>6 \mu \mathrm{M}$ at ambient temperature (Figure $2 \mathrm{~A}$ ). Thereafter the concentration of DIN decreased in all treatments, to an average of $0.31 \mu \mathrm{M}$ at day 12 . The concentration of DISi ( $\mathrm{Si}$ ) remained $>10 \mu \mathrm{M}$ in all treatments throughout the experiment (Figure 2B), with lower concentrations at elevated temperature at day 12 as compared to ambient. The concentration of DIP $\left(\mathrm{PO}_{4}^{3-}\right)$ was $<0.25 \mu \mathrm{M}$ in all treatments day 0 . From day 1 , the concentration of $\mathrm{PO}_{4}^{3-}$ (DIP) remained $>2 \mu \mathrm{M}$ in all treatments throughout the experiment (Figure $2 \mathrm{C}$ ). The addition of DIP changed the DIN:DIP ratio from an average of 38.66 at day 0 to an average of 0.03 at elevated temperature and 1.85 at ambient temperature at day 3 and, from day 3 and onwards, the average DIN:DIP ratio remained $<0.14$ in all treatments (Table 2).

\section{Photosynthetic activity and PAR levels}

There was a significant interaction between sampling day and temperature on $\mathrm{F}_{\mathrm{v}} / \mathrm{F}_{\mathrm{m}}\left(\mathrm{p}<0.0001, \mathrm{~F}_{4,32}=28.9\right.$, LME). The $F_{v} / F_{m}$ decreased from day 0 to day 6 (Figure $3 \mathrm{~A}$ ) and did not differ between temperature treatments at these sampling days ( $p>0.990$, Tukey's test). $F_{v} / F_{m}$ increased from day 9 , with a significantly higher ratio at increased temperature as compared to ambient at days 9 and 12 $(p<0.0001$, Tukey's test). Interactions between temperature and sampling day were also observed for the RLCderived photosynthetic parameters (Figure 3B-D), $\alpha_{\text {PSII }}$ $\left(p=0.012, F_{3,19}=4.7\right.$, LME $), r_{\text {ETR }}\left(p=0.040, F_{3,19}=3.4\right.$, LME) and $\mathrm{E}_{\mathrm{k}}\left(\mathrm{p}=0.004, \mathrm{~F}_{3,19}=6.1, \mathrm{LME}\right)$. PAR was on average $150 \mu \mathrm{mol}$ photons $\mathrm{m}^{-2} \mathrm{~s}^{-1}$ at midday during the initiation of the experiment and ranged from 100 to 250 photons $\mathrm{m}^{-2}$ $\mathrm{s}^{-1}$ on average until day 8, when PAR decreased to around $50 \mu \mathrm{mol}$ photons $\mathrm{m}^{-2} \mathrm{~s}^{-1}$ until the end of the experiment (Figure 1B).

\section{Microplanktonic composition and specific growth rates}

Shannon's diversity index was significantly affected by time $\left(\mathrm{p}=0.001, \mathrm{~F}_{4,32}=6.3\right.$, LME) but not by temperature and $p \mathrm{CO}_{2}$; the index was significantly higher at day 0 compared to the following days $(\mathrm{p}<0.01$, Tukey's test). The biovolume of both centric and pennate diatoms was also significantly affected by time $\left(\mathrm{p}<0.0001, \mathrm{~F}_{4.32}=77.8\right.$ and 46.5, respectively, LME). The biovolume of all diatoms 
Table 1: Experimental conditions and treatments, including $\mathrm{pH}_{\mathrm{T}}$ (presented at in situ temperature), temperature $\left({ }^{\circ} \mathrm{C}\right.$ ), total alkalinity $\left(\mathrm{A}_{\mathrm{T}} ; \mu \mathrm{mol} \mathrm{kg}{ }^{-1}\right.$ ) and $p \mathrm{CO}_{2}$ ( $\mu$ atm).

\begin{tabular}{|c|c|c|c|c|c|}
\hline Day & Treatment & $\mathrm{pH}_{\mathrm{T}}$ & Temperature $\left({ }^{\circ} \mathrm{C}\right)$ & $A_{T}\left(\mu \mathrm{mol} \mathrm{kg}{ }^{-1}\right)$ & $p \mathrm{CO}_{2}$ ( $\left.\mu \mathrm{atm}\right)$ \\
\hline \multirow[t]{5}{*}{0} & $1^{\circ} \mathrm{C} 390 \mu \mathrm{atm}$ & $7.70 \pm 0.02$ & 3.4 & $1520 \pm 12$ & $802 \pm 44$ \\
\hline & $1^{\circ} \mathrm{C} 970 \mu \mathrm{atm}$ & $7.71 \pm 0.03$ & 3.4 & $1529 \pm 6$ & $804 \pm 47$ \\
\hline & $4^{\circ} \mathrm{C} 390 \mu \mathrm{atm}$ & $7.70 \pm 0.02$ & 4.4 & $1537 \pm 19$ & $813 \pm 41$ \\
\hline & $4^{\circ} \mathrm{C} 970 \mu \mathrm{atm}$ & $7.71 \pm 0.01$ & 4.4 & $1520 \pm 30$ & $797 \pm 24$ \\
\hline & Control & $7.76 / 7.72$ & $4.4 / 3.4$ & $1518 / 1507$ & $695 / 758$ \\
\hline \multirow[t]{5}{*}{3} & $1^{\circ} \mathrm{C} 390 \mu \mathrm{atm}$ & $7.81 \pm 0.01$ & 1.0 & $1548 \pm 10$ & $602 \pm 6$ \\
\hline & $1^{\circ} \mathrm{C} 970 \mu \mathrm{atm}$ & $7.60 \pm 0.04$ & 1.0 & $1542 \pm 13$ & $1002 \pm 97$ \\
\hline & $4^{\circ} \mathrm{C} 390 \mu \mathrm{atm}$ & $7.74 \pm 0.04$ & 4.6 & $1546 \pm 13$ & $746 \pm 62$ \\
\hline & $4^{\circ} \mathrm{C} 970 \mu \mathrm{atm}$ & $7.57 \pm 0.03$ & 4.6 & $1576 \pm 11$ & $1153 \pm 85$ \\
\hline & Control & $7.59 / 7.85$ & $4.6 / 1.0$ & $1514 / 1519$ & $1012 / 560$ \\
\hline \multirow[t]{5}{*}{6} & $1^{\circ} \mathrm{C} 390 \mu \mathrm{atm}$ & $7.84 \pm 0.05$ & 0.7 & $1575 \pm 8$ & $576 \pm 68$ \\
\hline & $1^{\circ} \mathrm{C} 970 \mu \mathrm{atm}$ & $7.61 \pm 0.05$ & 0.7 & $1579 \pm 12$ & $988 \pm 115$ \\
\hline & $4^{\circ} \mathrm{C} 390 \mu \mathrm{atm}$ & $7.84 \pm 0.03$ & 4.5 & $1566 \pm 5$ & $598 \pm 43$ \\
\hline & $4^{\circ} \mathrm{C} 970 \mu \mathrm{atm}$ & $7.61 \pm 0.04$ & 4.5 & $1570 \pm 10$ & $1043 \pm 98$ \\
\hline & Control & No data & $4.5 / 0.7$ & No data & No data \\
\hline \multirow[t]{5}{*}{9} & $1^{\circ} \mathrm{C} 390 \mu \mathrm{atm}$ & $7.86 \pm 0.02$ & 1.4 & $1557 \pm 26$ & $539 \pm 23$ \\
\hline & $1^{\circ} \mathrm{C} 970 \mu \mathrm{atm}$ & $7.63 \pm 0.05$ & 1.4 & $1567 \pm 11$ & $933 \pm 107$ \\
\hline & $4^{\circ} \mathrm{C} 390 \mu \mathrm{atm}$ & $7.80 \pm 0.01$ & 4.4 & $1574 \pm 5$ & $669 \pm 22$ \\
\hline & $4^{\circ} \mathrm{C} 970 \mu \mathrm{atm}$ & $7.59 \pm 0.02$ & 4.4 & $1569 \pm 8$ & $1070 \pm 58$ \\
\hline & Control & $7.60 / 7.76$ & $4.4 / 1.4$ & $1525 / 1535$ & $1156 / 718$ \\
\hline \multirow[t]{5}{*}{12} & $1^{\circ} \mathrm{C} 390 \mu \mathrm{atm}$ & $7.85 \pm 0.02$ & 0.8 & $1556 \pm 49$ & $548 \pm 10$ \\
\hline & $1^{\circ} \mathrm{C} 970 \mu \mathrm{atm}$ & $7.58 \pm 0.02$ & 0.8 & $1573 \pm 6$ & $1053 \pm 50$ \\
\hline & $4^{\circ} \mathrm{C} 390 \mu \mathrm{atm}$ & $7.87 \pm 0.01$ & 4.4 & $1584 \pm 9$ & $564 \pm 14$ \\
\hline & $4^{\circ} \mathrm{C} 970 \mu \mathrm{atm}$ & $7.64 \pm 0.05$ & 4.4 & $1580 \pm 5$ & $978 \pm 119$ \\
\hline & Control & $7.60 / 7.78$ & $4.4 / 0.8$ & $1542 / 1535$ & $1099 / 675$ \\
\hline
\end{tabular}

$p \mathrm{CO}_{2}$ was derived from $\mathrm{pH}_{\mathrm{T}}, \mathrm{A}_{\mathrm{T}}$, temperature, salinity (6.6 throughout the experiment), inorganic phosphate and silicate concentration using CO2SYS (Pierrot et al. 2006). Data are presented for each treatment and controls ( $390 \mu \mathrm{atm} / 970 \mu$ atm for $\mathrm{pH}_{\mathrm{T}}, \mathrm{A}_{\mathrm{T}}$ and $p \mathrm{CO}_{2}$, and $1^{\circ} \mathrm{C} / 4^{\circ} \mathrm{C}$ for temperature). Controls represent aquaria incubated without the addition of any microplankton. Standard deviation is included when available, $n=3$.

Table 2: Nutrient stoichiometry and POC:PON ratios.

\begin{tabular}{|c|c|c|c|c|c|c|}
\hline Day & Treatment & POC & PON & POC:PON & DIN:DIP & POC organisms \\
\hline \multirow[t]{4}{*}{0} & $1^{\circ} \mathrm{C} 390 \mu \mathrm{atm}$ & $144.5 \pm 10.1$ & $17.3 \pm 0.9$ & $8.4 \pm 0.2$ & $38.8 \pm 0.9$ & $6.1 \pm 1.0$ \\
\hline & $1^{\circ} \mathrm{C} 970 \mu \mathrm{atm}$ & $168.5 \pm 16.3$ & $19.6 \pm 1.6$ & $8.6 \pm 0.2$ & $36.4 \pm 2.0$ & $6.7 \pm 1.6$ \\
\hline & $4^{\circ} \mathrm{C} 390 \mu \mathrm{atm}$ & $176.7 \pm 43.9$ & $20.6 \pm 4.8$ & $8.5 \pm 0.3$ & $41.0 \pm 3.0$ & $6.4 \pm 1.0$ \\
\hline & $4^{\circ} \mathrm{C} 970 \mu \mathrm{atm}$ & $230.7 \pm 51.8$ & $20.8 \pm 5.3$ & $11.3 \pm 2.3$ & $38.5 \pm 1.7$ & $6.4 \pm 1.0$ \\
\hline \multirow[t]{4}{*}{3} & $1^{\circ} \mathrm{C} 390 \mu \mathrm{atm}$ & No data & No data & No data & $1.7 \pm 0.1$ & $3.5 \pm 0.6$ \\
\hline & $1^{\circ} \mathrm{C} 970 \mu \mathrm{atm}$ & No data & No data & No data & $2.0 \pm 0.2$ & $3.9 \pm 0.7$ \\
\hline & $4^{\circ} \mathrm{C} 390 \mu \mathrm{atm}$ & No data & No data & No data & $<0.1 \pm 0.0$ & $3.6 \pm 0.2$ \\
\hline & $4^{\circ} \mathrm{C} 970 \mu \mathrm{atm}$ & No data & No data & No data & $<0.1 \pm 0.0$ & $3.3 \pm 0.9$ \\
\hline \multirow[t]{4}{*}{6} & $1^{\circ} \mathrm{C} 390 \mu \mathrm{atm}$ & No data & No data & No data & $0.1 \pm 0.0$ & $2.4 \pm 0.7$ \\
\hline & $1^{\circ} \mathrm{C} 970 \mu \mathrm{atm}$ & No data & No data & No data & $0.1 \pm 0.2$ & $1.9 \pm 0.3$ \\
\hline & $4^{\circ} \mathrm{C} 390 \mu \mathrm{atm}$ & No data & No data & No data & $0.1 \pm 0.1$ & $1.8 \pm 0.8$ \\
\hline & $4^{\circ} \mathrm{C} 970 \mu \mathrm{atm}$ & No data & No data & No data & $0.1 \pm 0.0$ & $2.0 \pm 0.7$ \\
\hline \multirow[t]{4}{*}{9} & $1^{\circ} \mathrm{C} 390 \mu \mathrm{atm}$ & No data & No data & No data & $0.09 \pm 0.02$ & $3.0 \pm 0.7$ \\
\hline & $1^{\circ} \mathrm{C} 970 \mu \mathrm{atm}$ & No data & No data & No data & $0.10 \pm 0.08$ & $2.2 \pm 0.5$ \\
\hline & $4^{\circ} \mathrm{C} 390 \mu \mathrm{atm}$ & No data & No data & No data & $0.12 \pm 0.01$ & $2.4 \pm 1.3$ \\
\hline & $4^{\circ} \mathrm{C} 970 \mu \mathrm{atm}$ & No data & No data & No data & $0.09 \pm 0.01$ & $2.0 \pm 0.7$ \\
\hline \multirow[t]{4}{*}{12} & $1^{\circ} \mathrm{C} 390 \mu \mathrm{atm}$ & $178.0 \pm 42.6$ & $24.9 \pm 5.2$ & $7.1 \pm 0.5$ & $0.1 \pm 0.1$ & $2.9 \pm 1.3$ \\
\hline & $1^{\circ} \mathrm{C} 970 \mu \mathrm{atm}$ & $193.2 \pm 45.8$ & $28.4 \pm 6.6$ & $6.8 \pm 0.1$ & $0.1 \pm 0.0$ & $1.5 \pm 0.5$ \\
\hline & $4^{\circ} \mathrm{C} 390 \mu \mathrm{atm}$ & $127.5 \pm 25.1$ & $15.3 \pm 3.2$ & $8.4 \pm 0.1$ & $0.1 \pm 0.0$ & $2.8 \pm 0.2$ \\
\hline & $4^{\circ} \mathrm{C} 970 \mu \mathrm{atm}$ & $132.0 \pm 10.0$ & $15.0 \pm 2.0$ & $8.9 \pm 0.5$ & $0.1 \pm 0.0$ & $2.2 \pm 0.8$ \\
\hline
\end{tabular}

Particulate organic carbon (POC) and particulate organic nitrogen (PON) are presented as $\mu \mathrm{M}, \mathrm{POC}: \mathrm{PON}$ ratio and dissolved inorganic nitrogen:phosphate ratio (DIN:DIP) as mol:mol, and POC organisms, based on microalgal biovolume calculation from microscopy analysis, as $\mu$ m. Standard deviation is included, $n=3$. 

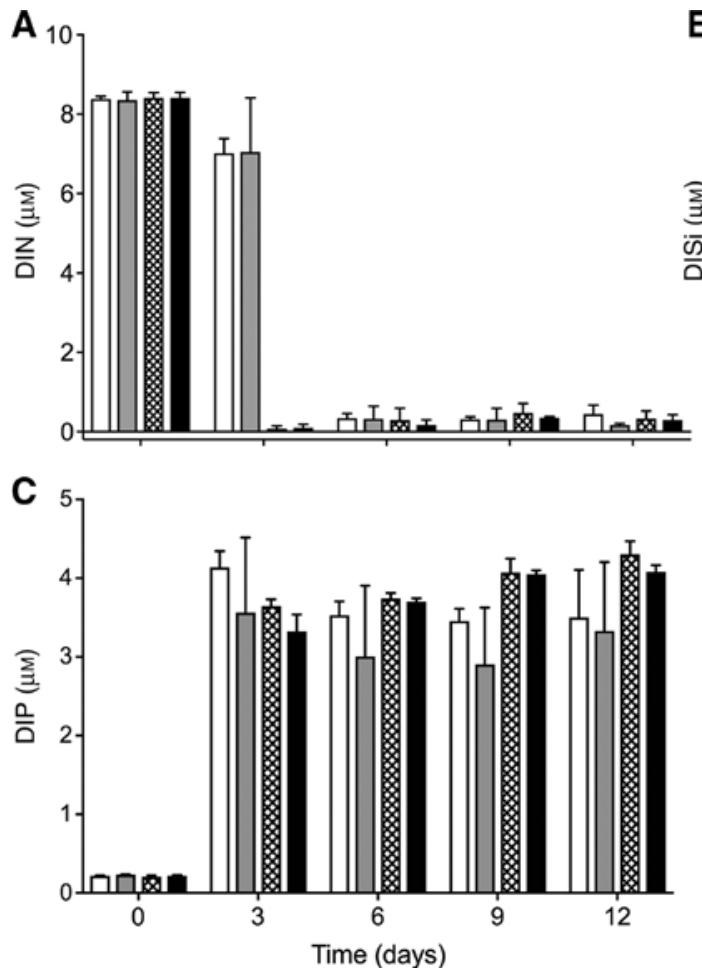

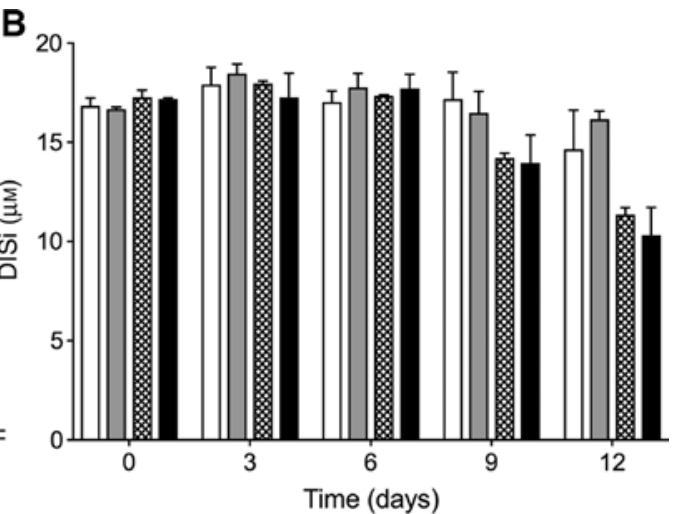

Time (days)

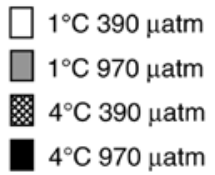

Figure 2: Inorganic nutrient concentrations in different temperature and $p \mathrm{CO}_{2}$ treatments.

(A) Dissolved inorganic nitrogen (DIN; $\mathrm{NO}_{3}{ }^{-}+\mathrm{NO}_{2}{ }^{-}$). (B) Dissolved inorganic silica (DISi). (C) Dissolved inorganic phosphate (DIP). Error bars indicate standard deviation, $\mathrm{n}=3$.
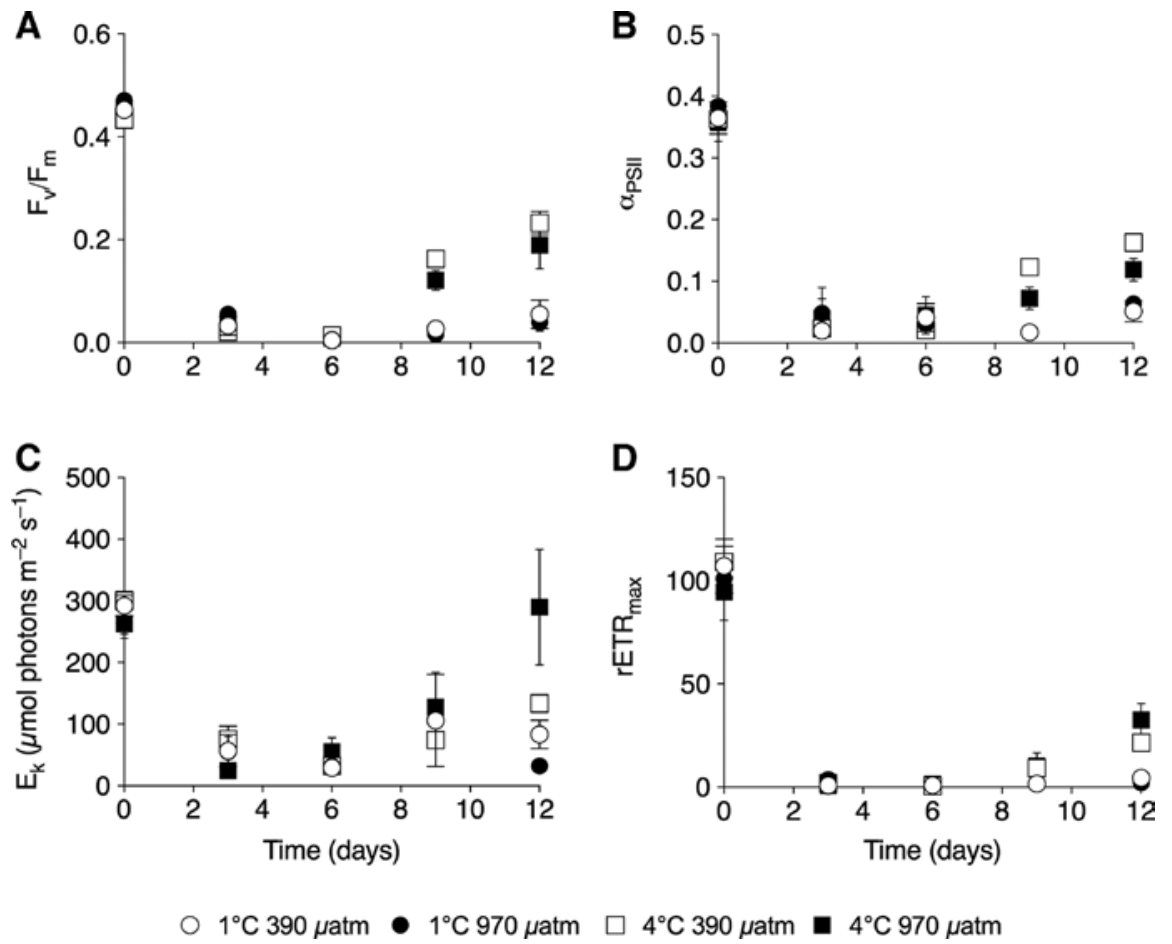

Figure 3: Photosynthetic activity of phytoplankton in different temperature and $p \mathrm{CO}_{2}$ treatments.

(A) Maximum quantum yield: $F_{v} / F_{m}$. (B) Initial slope of the rapid light curve (photosynthetic efficiency): $\alpha_{\text {PSI. }}$ (C) Minimum saturation irradiance: $E_{k}\left(\mu\right.$ mol photons $\mathrm{m}^{-2} \mathrm{~s}^{-1}$ ). (D) Maximum relative electron transport rate: $r E T R_{\max }$. Error bars indicate standard deviation, $\mathrm{n}=3$. 

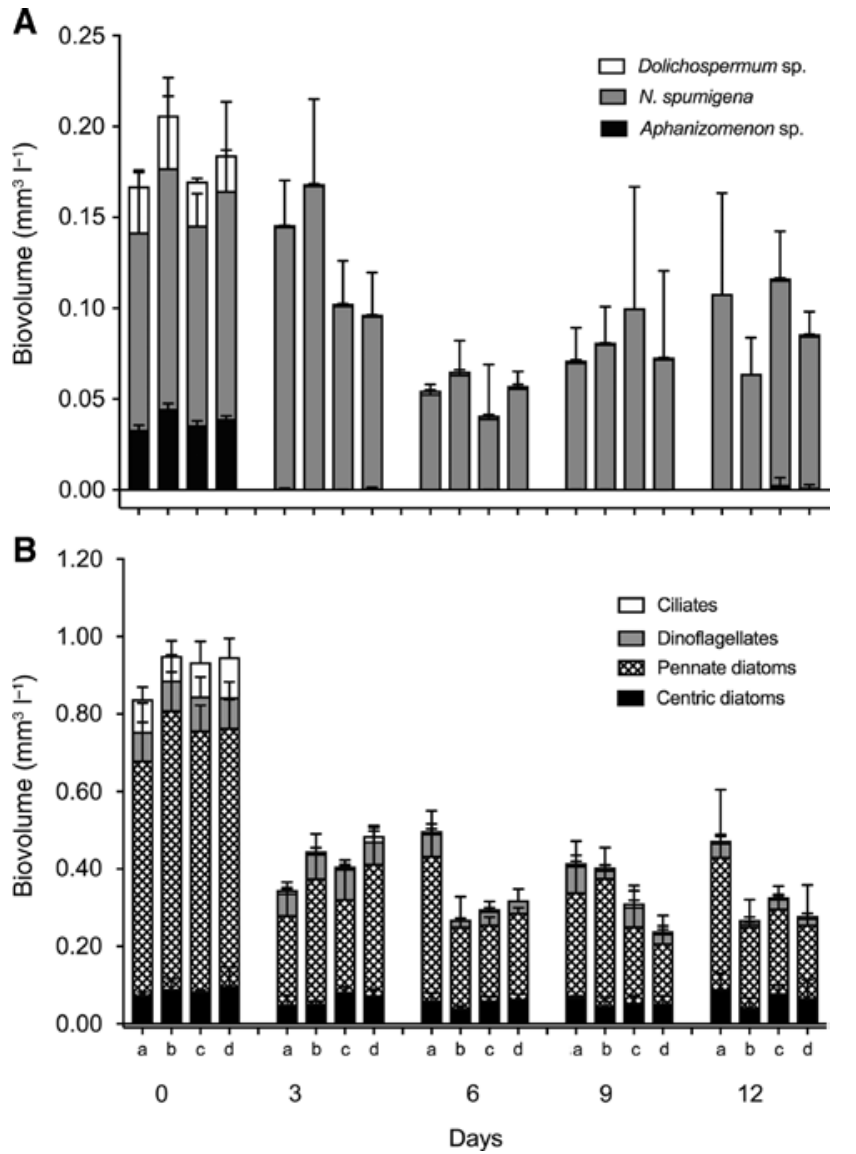

Figure 4: Biovolume $\left(\mathrm{mm}^{3} \mathrm{l}^{-1}\right)$ of phytoplankton in different temperature and $p \mathrm{CO}_{2}$ treatments $\left(\mathrm{a}: 1^{\circ} \mathrm{C} 390 \mu \mathrm{atm}, \mathrm{b}: 1^{\circ} \mathrm{C} 970 \mu \mathrm{atm}\right.$, c: $4^{\circ} \mathrm{C} 390 \mu \mathrm{atm}$, and d: $\left.4^{\circ} \mathrm{C} 970 \mu \mathrm{atm}\right)$.

(A) Biovolume of filamentous cyanobacteria. (B) Biovolume of ciliates, dinoflagellates, pennate diatoms and centric diatoms. Error bars indicate standard deviation, $\mathrm{n}=3$.

(Figure 4B) significantly decreased between days 0 and 3 ( $p<0.0001$, Tukey's test) but then remained stable in all treatments until day 12. Neither the biovolume of pennate nor of centric diatoms showed any treatment effects at day 12 (Figure 4B). No treatment effects were found for dinoflagellates and ciliates day 12. No differences between the treatments were found for the specific growth rate of diatoms and dinoflagellates between days 6 and 12 .

The biovolume of the three inoculated filamentous cyanobacteria species (Nodularia spumigena, Aphanizomenon sp. and Dolichospermum sp.; Figure 4A) was significantly affected by time $\left(\mathrm{p}<0.0001, \mathrm{~F}_{4,32}=9.1,1991.6\right.$ and 148.7, respectively, LME), and significantly decreased between days 0 and 6 ( $\mathrm{p}<0.0001$, Tukey's test). Thereafter, the biovolume of $N$. spumigen a slightly increased, but there was no significant difference between treatments at day 12 . Aphanizomenon sp. and Dolichospermum sp. were almost non-detectable between days 3 and 9, and cells were only occasionally found at elevated temperature at day 12. For $N$. spumigena, an average specific growth rate of $0.10 \pm 0.13$ $\mathrm{d}^{-1}$ was observed between days 6 and 12, with no significant difference between the treatments. No specific growth rate could be calculated for Aphanizomenon sp. and Dolichospermum sp. due to lack of filaments at day 6 .

\section{Heterotrophic bacterial abundance and productivity}

The bacterial abundance increased for all treatments on days $0-6$, followed by a decrease until day 12 (Figure 5A). The bacterial abundance was significantly affected by sampling day $\left(\mathrm{p}<0.0001, \mathrm{~F}_{4,29}=312.4\right.$, LME $)$ and $p \mathrm{CO}_{2}$ $\left(p=0.003, F_{1,8}=17.8\right.$, LME), with an interaction effect $\left(\mathrm{p}<0.0001, \mathrm{~F}_{4,29}=60.3, \mathrm{LME}\right)$. There were also interaction
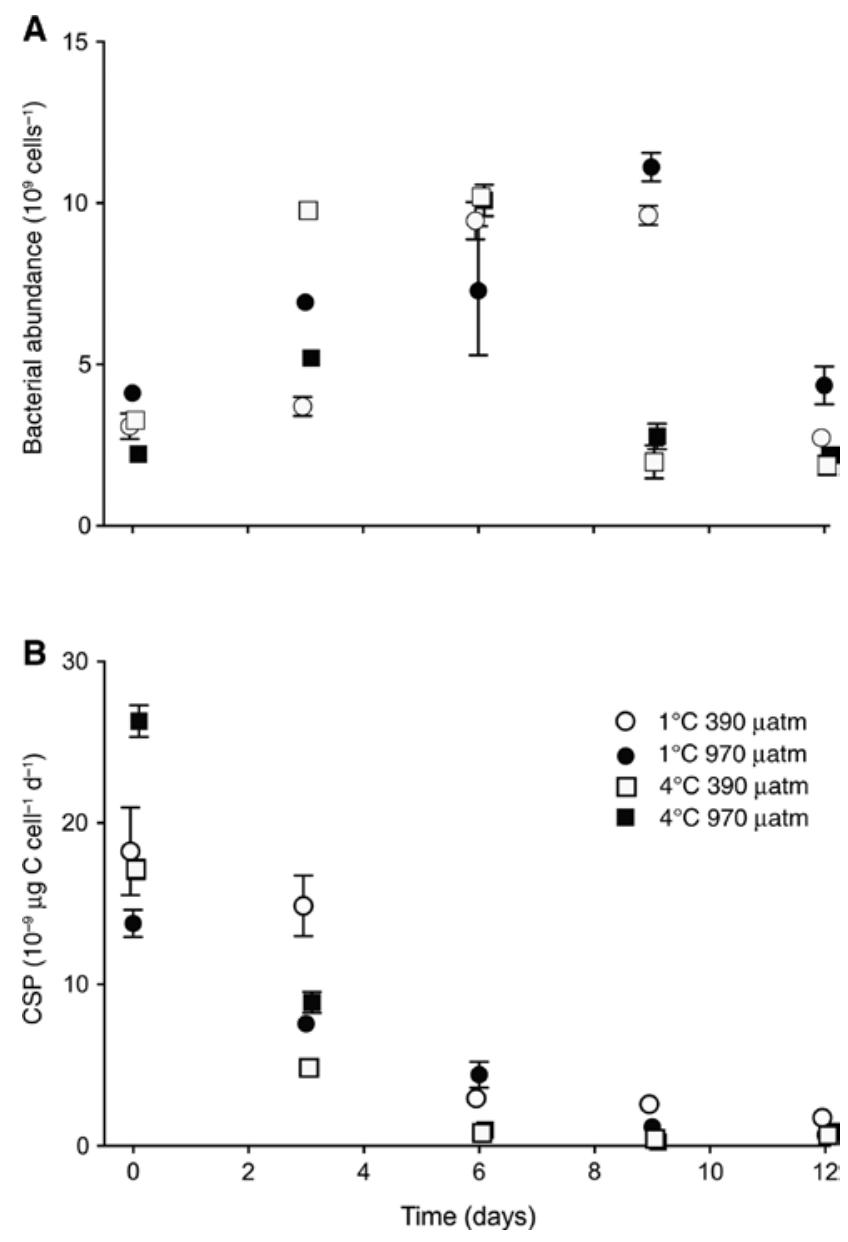

Figure 5: Heterotrophic bacterial abundance and bacterial production in different temperature and $p \mathrm{CO}_{2}$ treatments. (A) Bacterial abundance $\left(10^{9}\right.$ cells $\left.\mathrm{l}^{-1}\right)$. (B) Cell-specific production (CSP, $10^{-9} \mu \mathrm{g} \mathrm{C}$ cell $^{-1} \mathrm{~d}^{-1}$ ). Error bars indicate standard deviation, $\mathrm{n}=3$. 
effects for day and temperature $\left(\mathrm{p}<0.0001, \mathrm{~F}_{4,29}=76.0\right.$, LME), $p \mathrm{CO}_{2}$ and temperature ( $\left.\mathrm{p}<0.0001, \mathrm{~F}_{1,8}=71.0, \mathrm{LME}\right)$, and day, temperature and $\mathrm{CO}_{2}\left(\mathrm{p}<0.0001, \mathrm{~F}_{4,29}=44.8, \mathrm{LME}\right)$. No significant correlations were found between bacterial abundance and groups of phytoplankton. However, significant correlations were found between bacterial abundance and POC:PON ratio $\left(\mathrm{R}^{2}=0.41, \mathrm{p}=0.024, \mathrm{n}=12\right), \mathrm{POC}$ $\left(\mathrm{R}^{2}=0.35, \mathrm{p}=0.042, \mathrm{n}=12\right)$, and PON $\left(\mathrm{R}^{2}=0.48, \mathrm{p}=0.013\right.$, $\mathrm{n}=12$ ), with high bacterial abundance at high POC and PON concentrations and low POC:PON ratio. The cell-specific productivity (CSP; Figure $5 \mathrm{~B}$ ) was significantly affected by sampling day ( $p=0.026, F_{4,32}=3.2$, LME), gradually decreasing until day 9 ( $\mathrm{p}<0.01$, Tukey's test), and remaining stable on days 9 and 12 ( $p=0.99$, Tukey's test).

\section{Discussion}

This bi-factorial study aimed to test the resistance of a natural spring bloom community to increased temperature and elevated $p \mathrm{CO}_{2}$. In addition, we have tested whether diazotrophic filamentous cyanobacteria, normally dominating the Baltic Sea summer bloom, can compete with the natural spring bloom species under future climate change conditions. Interestingly, neither the biovolume of the natural spring bloom community nor the inoculated filamentous cyanobacteria were affected by elevated $p \mathrm{CO}_{2}$ or temperature conditions after being exposed for 12 days, thus, suggesting at least short-term resistance to fluctuations in the abiotic factors tested. Phytoplankton are known to have strategies to cope with environmental heterogeneities, such as changes in light conditions and nutrient supply, as they are mixed in the water column (e.g. Boyd et al. 2016). While Baltic Nodularia spumigena usually thrives at high temperatures and is mostly found at high densities during late summer (Suikkanen et al. 2010, Klawonn et al. 2016), we found it to be persistent and capable of growing at low temperature $\left(\leq 4^{\circ} \mathrm{C}\right)$. Overall, the filamentous cyanobacteria did not outcompete the natural spring bloom species under these conditions.

\section{Natural spring bloom community response to elevated temperature and $p \mathrm{CO}_{2}$}

All PSII parameters $\left(\mathrm{F}_{\mathrm{v}} / \mathrm{F}_{\mathrm{m}}, \alpha_{\text {PSII }}, \mathrm{rETR}_{\max }\right.$ and $\left.\mathrm{E}_{\mathrm{k}}\right)$ decreased together with the drop in DIN concentration and phytoplankton biovolume but recovered by the end of the experiment. The initial decrease in DIN concentration at elevated temperature can possibly be explained by a relatively higher affinity for $\mathrm{NO}_{3}^{-}$in the phytoplankton (Reay et al. 1999). Also, the sudden drop in photosynthetic parameters suggests that the cells became nutrient stressed early on in the experiment (Beardall et al. 2001). $\mathrm{F}_{\mathrm{v}} / \mathrm{F}_{\mathrm{m}}, \alpha_{\mathrm{PSII}}, \mathrm{rETR}_{\max }$ and $\mathrm{E}_{\mathrm{k}}$ were significantly higher at elevated temperatures as compared to ambient levels after 12 days, indicating that even though the total biovolume of phytoplankton was not yet affected by temperature, the cells were more active. The slow increase in photosynthetic parameters may have been triggered by regeneration of $\mathrm{N}$ through the decomposition of the initial standing stock of phytoplankton, or potentially from $\mathrm{N}_{2}$-fixation by $\mathrm{Nodu}$ laria spumigena. This strain of $N$. spumigena was recently shown to perform high rates of $\mathrm{N}_{2}$-fixation in culture (Olofsson et al. 2016). From days 9 to 12 we observed a decrease in Si concentration at elevated temperature, suggesting that diatoms were the main contributor to the increase in photosynthetic activity, but this was not reflected in the biovolume (or cell numbers) of diatoms. Silica-scaled chrysophytes have been observed in the Baltic Sea, but a more likely explanation may be that diatoms attached to the walls of the aquaria were missed out in the sampling. Also, the assimilation of $\mathrm{Si}$ by diatoms increases with temperature, possibly explaining the decrease from day 9 to day 12 at elevated temperature (Martin-Jézéquel et al. 2000).

No short-term effects of elevated $p \mathrm{CO}_{2}$ were observed on the biovolumes of diatoms and dinoflagellates. Previously documented short-term effects on diatoms include enhanced photosynthesis and carbon production (Wu et al. 2010, Yang and Gao 2012, Liu et al. 2017), while longterm studies have reported decreased growth rate and increased rates of respiration (7 months incubation in Torstensson et al. 2015, 1800 generations in Li et al. 2017). In a large-scale Baltic Sea mesocosm experiment, no effect on primary productivity at elevated $p \mathrm{CO}_{2}$ (ca. $1330 \mu \mathrm{atm}$ ) was observed, while a decreased respiration rate was detected after 31 days (Spilling et al. 2016). These previous studies point at the large variation between species, incubation times and environmental conditions affecting the outcome of experimental treatments. Our study highlights the resistance to short-term fluxes by the phytoplankton community, where no major effects by elevated $p \mathrm{CO}_{2}$ were found after 12 days. However, minor effects on species levels were detected, where the pennate diatom $(10-40 \mu \mathrm{m})$ and the dinoflagellate Peridiniella catenata (Levander) Balech 1977 were negatively affected by the elevated temperature and $p \mathrm{CO}_{2}$, respectively (Supplementary Tables S1, S2). At day 12, there were higher concentrations of POC and PON at ambient temperature as compared to elevated, which may be related to organisms 
of 1-8 $\mu \mathrm{m}$, like nano- and picoflagellates, present in the Baltic (Kuuppo 1994), which was not in focus in this study.

\section{Response of filamentous cyanobacteria to elevated temperature and $p \mathrm{CO}_{2}$}

Filamentous cyanobacteria are important N-sources in the Baltic Sea during summer. Overall, Aphanizomenon sp. contributes the most to $\mathrm{N}_{2}$-fixation due to its high biomass (Klawonn et al. 2016) and sustains high $\mathrm{N}_{2}$-fixation rates already at $10^{\circ} \mathrm{C}$ during early spring (Svedén et al. 2015). In the present study, the DIN:DIP ratio was $<3$ from day 3 onwards, similar to late-spring conditions, which may stimulate growth of cyanobacteria (Larsson et al. 2001). Anyhow, the filamentous cyanobacteria in our study were not able to outcompete the natural spring bloom species at low temperatures. Recovery was occurring faster at higher temperature, which was interestingly not (yet) reflected in biovolume and specific growth rates. The early acclimation of PSII is most likely occurring faster than what can be observed in growth, as the light-dependent reactions generally respond rapidly and growth encompasses many more processes than photochemistry.

An earlier start of the summer season has recently been predicted in a future climate change scenario (Kahru et al. 2016). Both Aphanizomenon sp. and Nodularia spumigena are present in low concentrations during winter in the Baltic Sea, but so far very little is known about their wintertime activity (Suikkanen et al. 2010, Wasmund 2017). During winter, Aphanizomenon sp. appears in higher abundance than $N$. spumigena in the Baltic Sea and, thus, possibly exhibits different survival strategies in terms of initial biomass in a pre-bloom situation (Wasmund 2017). Even though the low temperature $\left(\leq 4^{\circ} \mathrm{C}\right)$ is far from optimal growth temperatures for the filamentous cyanobacteria (Suikkanen et al. 2010), the increase in biomass of $N$. spumigena from day 6 onwards indicates rapid acclimation to the experimental conditions in this strain. Thus, we suggest that $N$. spumigena has a potential to grow during spring bloom conditions. The biovolume of Aphanizomenon sp. decreased at the initiation of the experiment, as also observed by Wulff et al. (2018), thus, no temperature effects could be observed.

Manipulations of the carbonate system using air bubbling to mimic future climate change scenarios have previously been used successfully (Gattuso et al. 2010, Karlberg and Wulff 2013, Torstensson et al. 2013, 2015, Wulff et al. 2018). A pH difference was established from day 3 onwards, even though specific $p \mathrm{CO}_{2}$ values are difficult to control because $p \mathrm{CO}_{2}$ also varies with photosynthesis and respiration rates (Wulff et al. 2018). Nevertheless, no effects of elevated $p \mathrm{CO}_{2}$ were found on the filamentous cyanobacteria. These results are consistent with some previous studies (Paul et al. 2016, Wulff et al. 2018), while others show increased growth (Wannicke et al. 2012, Eichner et al. 2014). Also, filamentous cyanobacteria are known to cope with daily fluctuations in $\mathrm{pH}$ measured both in aggregates (Ploug 2008) and in situ conditions (Wulff et al. 2018).

\section{Response of heterotrophic bacteria to elevated temperature and $p \mathrm{CO}_{2}$}

Growth of heterotrophic bacteria is limited by temperature during most of the year in the Baltic Sea (Hagström and Larsson 1984). Nevertheless, no response in bacterial abundance to higher temperature was observed in our experiment, which may indicate that in early spring an increase of $3^{\circ} \mathrm{C}$ would not stimulate bacterial growth. Consistent with earlier work (Burrell et al. 2017), bacterial abundance was not affected by the increase in $p \mathrm{CO}_{2}$. The observed early increase in abundance and productivity in all treatments (up to day 6) may be due to the release of DOC from surrounding phytoplankton (Engel et al. 2013, Torstensson et al. 2015). After day 6, the decline in bacterial abundance may suggest that bacterial mortality agents (grazers or viruses) increased, especially at higher temperature. Indeed, the grazing by heterotrophic flagellates has been shown to increase with temperature in the Baltic Sea Proper (Riemann et al. 2008). In addition, other work suggests that virus-induced bacterial mortality might be particularly sensitive to temperature variations in cold environments (Vaqué et al. 2017). Hence, while we did not examine viruses and flagellates $(<8 \mu \mathrm{m})$ in the present experiment, they may potentially play central roles for the biogeochemical cycling of nutrients and energy through the planktonic microbial loop, particularly at the low temperatures prevailing in early spring.

In conclusion, increased $p \mathrm{CO}_{2}$ and temperature did not enhance filamentous cyanobacteria over the natural spring bloom species, but the overall higher photosynthetic activity at elevated temperatures during the latter part of the experiment indicated more active cells within the community. For the toxic Nodularia spumigena, a positive specific growth rate during the second half of the experiment reflects its successful acclimation to temperatures $\leq 4^{\circ} \mathrm{C}$ and indicates a putative ecological relevance also during wintertime in the Baltic Sea. Our results highlight the resistance of the natural spring bloom community to short-term variations in abiotic conditions and, as 
such, suggest only limited microplankton responses to the $p \mathrm{CO}_{2}$ and temperature levels predicted.

Acknowledgments: This study was supported by the Association of European Marine Biological Laboratories (ASSEMBLE, no. 227799) and by a guest scholarship of the Swedish Institute (00185/2010). We thank Nina Ekstrand for chemical analyses at Kristineberg, and My Mattsdotter Björk for helping out with data analysis. Also, thanks to Monica Appelgren for keeping the algal bank and providing cultures of filamentous cyanobacteria, to the staff at Askö marine field station for helping with water collection, and also to the staff at Sven Lovén centre, Kristineberg, for assistance during the experiment. The funding source did not have a role in the data collection, analysis and interpretation nor in the writing of the present publication.

\section{References}

Andersson, A., P. Haecky and Å. Hagström. 1994. Effect of temperature and light on the growth of micro- nano- and pico-plankton: impact on algal succession. Mar. Biol. 120: 511-520.

Andersson, A., H.E.M. Meier, M. Ripszam, O. Rowe, J. Wikner, P. Haglund, K. Eilola, C. Legrand, D. Figueroa, J. Paczkowska, E. Lindehoff, M. Tysklind and R. Elmgren. 2015. Projected future climate change and Baltic Sea ecosystem management. AMBIO 44: S345-S356.

Beardall, J., E. Young and S. Roberts. 2001. Approaches for determining phytoplankton nutrient limitation. Aquat. Sci. 63: 44-69.

Bentzon-Tilia, M., S.J. Traving, M. Mantikci, H. Knudsen-Leerbeck, J.L. Hansen, S. Markager and L. Riemann L. 2015. Significant $\mathrm{N}_{2}$ fixation by heterotrophs, photoheterotrophs and heterocystous cyanobacteria in two temperate estuaries. ISME J. 9: 273-285.

Blais, M., J.-E. Tremblay, A.D. Jungblut, J. Gagnon, J. Martin, M. Thaler and C. Lovejoy. 2012. Nitrogen fixation and identification of potential diazotrophs in the Canadian Arctic. Glob. Biogeochem. Cycl. 26: GB3022.

Boyd, P.W., C.E. Cornwall, A. Davison, S.C. Doney, M. Fourquez, C.L. Hurd, I.D. Lima and A. McMinn. 2016. Biological responses to environmental heterogeneity under future ocean conditions. Global Change Biol. 22: 2633-2650.

Burrell, T.J., E.W. Maas, D.A. Hulston and C.S. Law. 2017. Variable response to warming and ocean acidification by bacterial processes in different plankton communities. Aquat. Microb. Ecol. 79: 49-62.

Chierici, M., A. Fransson and L.G. Anderson. 1999. Influence of $\mathrm{m}$-cresol purple indicator additions on the $\mathrm{pH}$ of seawater samples: correction factors evaluated from a chemical speciation model. Mar. Chem. 65: 281-290.

Clayton, T.D., R.H. Byrne, J.A. Breland, R.A. Feely, F.J. Millero, D.M. Campbell, P.P. Murphy and M.F. Lamb. 1995. The role of $\mathrm{pH}$ measurements in modern oceanic $\mathrm{CO}_{2}$ system characterizations: precision and thermodynamic consistency. Deep-Sea Res. Pt II 42: 411-429.

Davis, T.W., D.L. Berry, G.L. Boyer and C.J. Gobler. 2009. The effects of temperature and nutrients on the growth and dynamics of toxic and non-toxic strains of Microcystis during cyanobacteria blooms. Harmful Algae 8: 715-725.

Dickson, A.G. 1990. Standard potential of the reaction: $\mathrm{AgCl}(\mathrm{s})+$ $1 / 2 \mathrm{H}_{2}(\mathrm{~g})=\mathrm{Ag}(\mathrm{s})+\mathrm{HCl}(\mathrm{aq})$, and the standard acidity constant of the ion $\mathrm{HSO}_{4}$ in synthetic sea water from 273.15 to $318.15 \mathrm{~K}$. J. Chem. Thermodyn. 22: 113-127.

Dickson, A.G. and F.J. Millero. 1987. A comparison of the equilibrium constants for the dissociation of carbonic acid in seawater media. Deep-Sea Res. I 34: 1733-1743.

Dickson, A.G., C.L. Sabine and J.R. Christian. 2007. Guide to Best Practices for Ocean $\mathrm{CO}_{2}$ Measurements, PICES Special Publication 3, North Pacific Marine Science Organization, Sidney, Canada.

Eichner, M., B. Rost and S.A. Kranz. 2014. Diversity of ocean acidification effects on marine $\mathrm{N}_{2}$ fixers. J. Exp. Mar. Biol. Ecol. 457: 199-207.

Engel, A., C. Borchard, J. Piontek, K.G. Schulz, U. Riebesell and R. Bellerby. 2013. $\mathrm{CO}_{2}$ increases ${ }^{14} \mathrm{C}$ primary production in an Arctic plankton community. Biogeosciences 10: 1291-1308.

Fu, F.-X., M.E. Warner, Y. Zhang, Y. Feng and D.A. Hutchins. 2007. Effects of increased temperature and $\mathrm{CO}_{2}$ on photosynthesis, growth, and elemental ratios in marine Synechococcus and Prochlorococcus (Cyanobacteria). J. Phycol. 43: 485-496.

Fuhrman, J.A. and F. Azam. 1982. Thymidine incorporation as a measure of heterotrophic bacterioplankton production in marine surface waters: evaluation and field results. Mar. Biol. 66: 109-120.

Gasol, J.M. and P.A. del Giorgio. 2000. Using flow cytometry for counting natural planktonic bacteria and understanding the structure of planktonic bacterial communities. Scientia Marina 64: 197-224.

Gattuso, J.P., K. Gao, K. Lee, B. Rost and K.G. Schulz. 2010. Approaches and tools to manipulate the carbonate chemistry. In: (U. Riebesell, V.J. Fabry, L. Hansson and J.P. Gattuso, eds) Guide to best practices for ocean acidification research and data reporting. Publications Office of the European Union, Luxembourg. pp. 41-52.

Gran, G. 1952. Determination of the equivalence point in potentiometric titrations. Part II. Analyst 77: 661-671.

Grasshoff, K., K. Kremling and M. Ehrhardt. 1999. Methods of seawater analysis. 3rd edition, Wiley-VHC, Weinheim, DE.

Groetsch, P.M.M., S.G.H. Simis, M.A. Eleveld and S.W.M. Peters. 2016. Spring blooms in the Baltic Sea have weakened but lengthened from 2000 to 2014. Biogeosciences 13: 4959-4973.

Hagström, Å. and U. Larsson. 1984. Diel and seasonal variation in growth rates of pelagic bacteria. In: (J.E. Hobbie and P.J.L. Williams, eds) Heterotrophic activity in the sea. Plenum, New York. pp. 249-262.

Haraldsson, C., L.G. Anderson, M. Hassellov, S. Hulth and K. Olsson. 1997. Rapid, high-precision potentiometric titration of alkalinity in the ocean and sediment pore waters. Deep-Sea Res. 144: 2031-2044.

Hillebrand, H., C.-D. Dürselen, D. Kirschtel, U. Pollingher and T. Zohary. 1999. Biovolume calculation for pelagic and benthic microalgae. J. Phycol. 35: 403-424. 
HELCOM. 2013. Climate change in the Baltic Sea Area: HELCOM thematic assessment in 2013, Balt. Sea Environ. Proc. No. 137.

HELCOM. 2014a. Annex C-6: Guidelines concerning phytoplankton species composition, abundance and biomass. In: Manual for Marine Monitoring in the COMBINE Programme of HELCOM. http://www.helcom.fi/helcom-at-work/publications/manualsand-guidelines/ Accessed June 2018.

HELCOM. 2014b. Annex C-11: Guidelines concerning bacterioplankton growth determination. In: Manual for Marine Monitoring in the COMBINE Programme of HELCOM. http://www.helcom. fi/helcom-at-work/publications/manuals-and-guidelines/ Accessed June 2018.

IPCC. 2013. Climate change: the physical science basis. Contribution of working group I to the fifth assessment report of the Intergovernmental Panel on Climate Change. In: (T.F. Stocker, D. Qin, G-K. Plattner, M. Tignor, S.K. Allen, J. Boschung, A.Y.X. Nauels, V. Bex and P.M. Midgley, eds) Cambridge University Press, Cambridge, United Kingdom and New York, NY, USA.

Jassby, A.D. and T. Platt. 1976. Mathematical formulation of the relationship between photosynthesis and light for phytoplankton. Limnol. Oceanogr. 21: 540-547.

Kahru, M., R. Elmgren and O.P. Savechuk. 2016. Changing seasonality of the Baltic Sea. Biogeosciences 13: 1009-1018.

Karlberg, M. and A. Wulff. 2013. Impact of temperature and species interaction on filamentous cyanobacteria may be more important than salinity and increased $p \mathrm{CO}_{2}$ levels. Mar. Biol. 160: 2063-2072.

Klawonn, I., N. Nahar, J. Walve, B. Andersson, M. Olofsson, B.J. Svedén, S. Littmann, M.J. Whitehouse and H. Ploug. 2016. Cell-specific nitrogen- and carbon-fixation of cyanobacteria in a temperate marine system (Baltic Sea). Environ. Microb. 18: 4596-4609.

Kuuppo, P. 1994. Annual variation in the abundance and size of heterotrophic nanoflagellates on the SW coast of Finland, the Baltic Sea. J. Plankton Res. 16: 1525-1542.

Larsson, U., S. Hajdu, J. Walve and R. Elmgren. 2001. Baltic Sea nitrogen fixation from the summer increase in upper mixed layer total nitrogen. Limnol. Oceanogr. 46: 811-820.

Lee, S. and J.A. Fuhrman. 1987. Relationship between biovolume and biomass of naturally derived marine bacterioplankton. Appl. Environ. Microbiol. 53: 1298-1303.

Lenth, R.V. 2016. Least-squares means: the R package Ismeans. J. Stat. Softw. 69: 1-33.

Li, F., J. Beardall, S. Collins and K. Gao. 2017. Decreased photosynthesis and growth with reduced respiration in the model diatom Phaeodactylum tricornutum grown under elevated $\mathrm{CO}_{2}$ over 1800 generations. Global Change Biol. 23: 127-137.

Liu, X., Y. Li, Y. Wu, B. Huang, M. Dai, F. Fu, D.A. Hutchins and K. Gao. 2017. Effects of elevated $\mathrm{CO}_{2}$ on phytoplankton during a mesocosm experiment in the sothern eutrophicated coastal water of China. Sci. Rep. 7: 6868.

Martin-Jézéquel, V., M. Hildebrand and M.A. Brzezinski. 2000. Silicon metabolism in diatoms: implications for growth. J. Phycol. 36: 821-840.

Mehrbach, C., C.H. Culberson, J.E. Hawley and R.M. Pytkowicz. 1973. Measurement of the apparent dissociation constants of carbonic acid in seawater at atmospheric pressure. Limnol. Oceanogr. 18: 897-907.

Menden-Deuer, S. and E.J. Lessard. 2000. Carbon to volume relationship for dinoflagellates, diatoms and other protest plankton. Limnol. Oceanogr. 45: 569-579.
National oceanic and atmospheric administration (NOAA), U.S. Department of commerce. https://www.esrl.noaa.gov/gmd/ ccgg/trends/, for December 2017.

Olenina, I., S. Hajdu, L. Edler, A. Andersson, N. Wasmund, S. Busch, J. Göbel, S. Gromisz, S. Huseby, M. Huttunen, A. Jaanus, P. Kokkonen, I. Ledaine and E. Niemkiewicz. 2006. Biovolumes and size-classes of phytoplankton in the Baltic Sea. HELCOM Balt. Sea Environ. Proc. 106: 144.

Olofsson, M., J. Egardt, A. Singh and H. Ploug. 2016. Inorganic phosphorus enrichments in Baltic Sea water have large effects on growth, carbon- and $\mathrm{N}_{2}$-fixation by Nodularia spumigena. Aquat. Microb. Ecol. 77: 111-123.

Paerl, H.W. and J. Huisman. 2008. Blooms like it hot. Science 320: 57-58.

Paul, A.J., E.P. Achterberg, L.T. Bach, T. Boxhammer, J. Czerny, M. Haunost, K.-G. Schulz, A. Stuhr and U. Riebesell. 2016. No observed effect of ocean acidification on nitrogen biogeochemistry in a summer Baltic Sea plankton community. Biogeosciences 13: 3901-3913.

Pierrot, D., E. Lewis and D.W.R. Wallace. 2006. MS Excel Program developed for $\mathrm{CO}_{2}$ system calculations, ORNL/CDIAC-105. Carbon Dioxide Information Analysis Center, Oak Ridge National Laboratory, U.S. Department of Energy, Oak Ridge, Tennessee, USA.

Pinheiro, J., D. Bates, S. DebRoy and D. Sarkar. 2017. R Core Team. nlme: linear and nonlinear mixed effects models. $R$ package version 3.1-137. https://CRAN.R-project.org/package=nlme

Ploug, H. 2008. Cyanobacterial surface blooms formed by Aphanizomenon sp. and Nodularia spumigena in the Baltic Sea: small-scale fluxes, pH, and oxygen microenvironments. Limnol. Oceanogr. 53: 914-921.

Ploug, H., B. Adam, N. Musat, T. Kalvelage, G. Lavik, D. Wolf-Gladrow and M.M.M. Kuypers. 2011. Carbon, nitrogen and $\mathrm{O}_{2}$ fluxes associated with the cyanobacterium Nodularia spumigena in the Baltic Sea. ISME J. 5: 1549-1558.

Quinn, G.P. and M.J. Keough. 2002. Experimental design and data analysis for biologists. Cambridge University Press, Cambridge. pp. 173-207.

R Core Team. 2016. R: a language and environment for statistical computing. In R Core Team. https://www.R-project.org/, Version 3.1.1, R Foundation for Statistical Computing, Vienna, Austria.

Reay, D.S., D.B. Nedwell, J. Priddle and C. Ellis-Evans. 1999. Temperature dependence of inorganic nitrogen uptake: reduced affinity for nitrate at subopimal temperatures in both algae and bacteria. App. Environ. Microb. 65: 2577-2584.

Riemann, L., C. Leitet, T. Pommier, K. Simu, K. Holmfeldt, U. Larsson and Å. Hagström. 2008. The native bacterioplankton community in the central Baltic Sea is influenced by freshwater bacterial species. Appl. Environ. Microbiol. 74: 503-515.

Silsbe, G.M. and S.Y. Malkin. 2015. Phytotools: Phytoplankton Production Tools. https://CRAN.R-project.org/ package $=$ phytotools, Version 1.0 ed.

Smith, D.C. and F. Azam. 1992. A simple, economical method for measuring bacterial protein synthesis rates in seawater using 3H-leucine. Marine Microbial Food Webs 6:102-114.

Sommer, U., N. Aberle, K. Lengfellner and A. Lewandowska. 2012. The Baltic Sea spring phytoplankton bloom in a changing climate: an experimental approach. Mar. Biol. 159: 2479-2490.

Spilling, K., A.J. Paul, N. Virkkala, T. Hastings, S. Lischka, A. Stuhr, R. Bermúdez, J. Czerny, T. Boxhammer, K.G. Schulz, A. Ludwig and U. Riebesell. 2016. Ocean acidification decreases plankton 
respiration: evidence from a mesocosm experiment. Biogeosciences 13: 4707-4719.

Suikkanen, S., H. Kaartokallio, S. Hällfors, M. Huttunen and M. Laamanen. 2010. Life cycle strategies of bloom-forming, filamentous cyanobacteria in the Baltic Sea. Deep-Sea Res. PT II 57: 199-209.

Svedén, J.B., B. Adam, J. Walve, N. Nahar, N. Musat, G. Lavik, M.J. Whitehouse, M.M.M. Kuypers and H. Ploug. 2015. High cellspecific rates of nitrogen and carbon fixation by the cyanobacterium Aphanizomenon sp. at low temperatures in the Baltic Sea. FEMS Microbiol. Ecol. 91: fiv131.

Torstensson, A., M. Hedblom, J. Andersson, M.X. Andersson and A. Wulff. 2013. Synergism between elevated $p \mathrm{CO}_{2}$ and temperature on the Antarctic sea ice diatom Nitzschia lecointei. Biogeosciences 10: 6637-6669.

Torstensson, A., M. Hedblom, M.M. Björk, M. Chierici and A. Wulff. 2015. Long-term acclimation to elevated $p \mathrm{CO}_{2}$ alters carbon metabolism and reduces growth in the Antarctic diatom Nitzschia lecointei. P. Roy. Soc. B-Biol. Sci. 282: 20151513.

Vaqué, D., J. Boras, F. Torrent-Llagostera, S. Agusti, J.M. Jesús, E. Lara, Y.M. Castillo, C.M. Duarte and M.M. Sala. 2017. Viruses and protists induced-mortality of prokaryotes around the Antarctic Peninsula during the Austral summer. Front Microb. 8: 241.

Wannicke, N., S. Endres, A. Engel, H.P. Grossart, M. Nausch, J. Unger and M. Voss. 2012. Response of Nodularia spumigena to $p \mathrm{CO}_{2}$ - part 1: growth, production and nitrogen cycling. Biogeosciences 9: 2973-2988.

Wasmund, N. 2017. Recruitment of bloom-forming cyanobacteria from winter/spring populations in the Baltic Sea verified by a mesocosm approach. Boreal Env. Res. 22: 445-455.

Wasmund, N., G. Nausch and W. Matthäus. 1998. Phytoplankton spring blooms in the southern Baltic Sea-spatio-temporal development and long-term trends. J. Plankton Res. 20: 1099-1117.

Wejnerowski, L., P. Rzymski, M. Kokocinski and J. Meriluoto. 2018. The structure and toxicity of winter cyanobacterial bloom in a eutrophic lake of the temperate zone. Ecotoxicology 27: 752-760.

Wohlers, J., A. Engel, E. Zöllner, P. Breithaupt, K. Jürgens, H.-G. Hoppe, U. Sommer and U. Riebsell. 2009. Changes in biogenic carbon flow in response to sea surface warming. PNAS 106: 7067-7072.

Wu, Y., K. Gao and U. Riebesell. 2010. $\mathrm{CO}_{2}$-induced seawater acidification affects physiological performance of the marine diatom Phaeodactylum tricornutum. Biogeosciences 7: 2915-2923.

Wulff, A., M. Karlberg, M. Olofsson, A. Torstensson, L. Riemann, F.S. Steinhoff, M. Mohlin, N. Ekstrand and M. Chierici. 2018. Ocean acidification and desalination: climate-driven change in a Baltic Sea summer microplanktonic community. Mar. Biol. 165: 63.

Yang, G. and K. Gao. 2012. Physiological responses of the marine diatom Thalassiosira pseudonana to increased $\mathrm{pCO}_{2}$ and seawater acidity. Mar. Environ. Res. 79: 142-151.

Supplementary Material: The online version of this article offers supplementary material (https://doi.org/10.1515/bot-2018-0005).

\section{Bionotes}

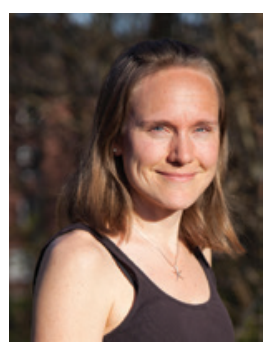

\section{Malin Olofsson}

University of Gothenburg, Department of Marine Sciences, Box 461, Gothenburg SE405 30, Sweden

malin.olofsson@marine.gu.se

Malin Olofsson received her PhD in Marine Sciences from the University of Gothenburg in June 2018. Her research centers on nutrient cycling associated to phytoplankton and heterotrophic bacteria. By quantifying single-cell assimilation of carbon and nitrogen using secondary ion mass spectrometry, her $\mathrm{PhD}$ thesis includes novel insights into nutrient uptake by single cells of phytoplankton within mixed natural communities. She has also revived 100 -year-old resting stages of diatoms in order to study single-cell dynamics in nutrient demands. Future research will include further studies on phytoplankton-bacterial interactions and carbon cycling.

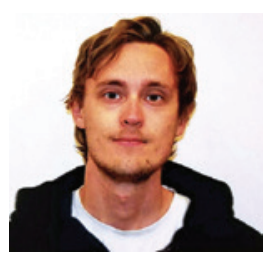

\section{Anders Torstensson}

University of Gothenburg, Department of Biological and Environmental Sciences, Box 461, Gothenburg SE-405 30, Sweden

Anders Torstensson is at the time of publication a postdoctoral researcher at Uppsala University, Sweden. He holds a PhD in Biology from the University of Gothenburg, Sweden, and has spent 2 years as a postdoctoral researcher at the School of Oceanography, University of Washington. His research mainly focuses on ecophysiology of sea-ice microalgae and bacteria with respect to ocean acidification and global warming.

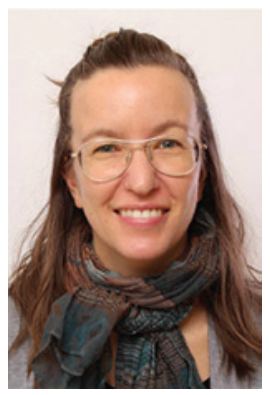

\section{Maria Karlberg}

University of Gothenburg, Department of Biological and Environmental Sciences, Box 461, Gothenburg SE-405 30, Sweden

Maria Karlberg holds a PhD in Biology from the University of Gothenburg, Sweden. She has published 5 peer-reviewed publications mainly focused on phytoplankton ecology, with particular emphasis on bloom-forming filamentous cyanobacteria in the Baltic Sea, effects of climate change and their potential source for biofuels. Karlberg is presently employed as a plankton expert at the Swedish Meteorological and Hydrological Institute (SMHI). 


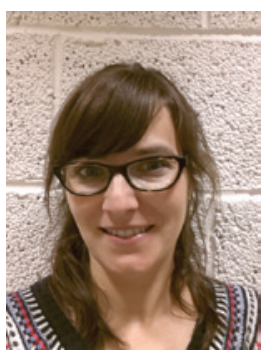

Franciska S. Steinhoff

University of Gothenburg, Department of Biological and Environmental Sciences, Box 461, Gothenburg SE-405 30, Sweden

Franciska S. Steinhoff received a PhD from Bremen University, Germany in 2010 investigating the effects of global environmental changes on brown macroalgae. While she was focused on biofuel production from cyanobacteria at the University of Gothenburg, Sweden, Steinhoff has also worked in the field of industrial ecology in Trondheim, Norway. She is currently holding a position at Felleskjøpet Fôrutvikling in Norway.

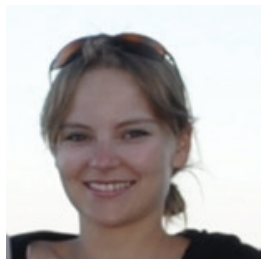

\section{Julie Dinasquet}

Scripps Institution of Oceanography, UC San Diego, 9500 Gilman Drive, La Jolla, CA 92093 0202, USA

University of Copenhagen, Marine Biological Section, Department of Biology, Strandpromenaden 5, Helsingør DK-3000, Denmark

Julie Dinasquet is a postdoctoral researcher at the Scripps Institution of Oceanography, in California. She did her PhD in marine microbiology between the Linnaeus University, Sweden and Copenhagen University, Denmark. She graduated in 2013 after which she received a EU Marie-Curie postdoctoral fellowship to work between the USA in France. Her research focuses on studying the role of micro-organisms in biogeochemical cycles, atmospheric chemistry, as well as food-web interactions.

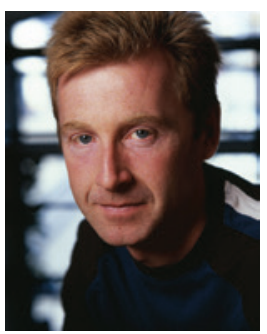

\section{Lasse Riemann}

University of Copenhagen, Marine Biological Section, Department of Biology, Strandpromenaden 5, Helsingør DK-3000, Denmark

Lasse Riemann is Professor in the Marine Biological Section, Department of Biology, University of Copenhagen, Denmark. He holds a $\mathrm{PhD}$ in marine microbiology from the University of Copenhagen. After doing parts of MSc/PhD at Scripps Institution of Oceanography, Riemann worked as Ass. Prof. and Assoc. Prof. at the University of Kalmar, Sweden. He returned as Assoc Prof to Univ. Copenhagen in 2010. Riemann has contributed to $>90$ peer-reviewed publications mainly focused on marine microbial ecology, with particular emphasis on the application of molecular tools to decipher bacterioplankton diversity, composition and functionality.

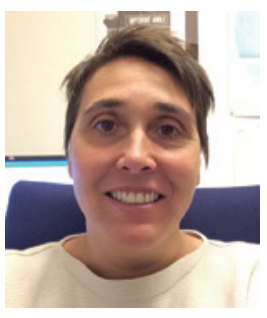

Melissa Chierici

Institute of Marine Research, Fram Centre, 9007, Troms $\emptyset$, Norway

Melissa Chierici, Sr. Scientist at Institute of Marine Research (Norway) and adj. Professor at University Centre in Svalbard is an observational marine chemist with more than 20 years expertise within the carbon cycle, carbonate chemistry, and ocean acidification. Her current research focus is on the natural and anthropogenic drivers controlling the oceans shifting carbonate chemistry, and the effects of climate stressors on organisms using both field observations as well as experimental studies. This has resulted in nearly 60 peer-review articles.

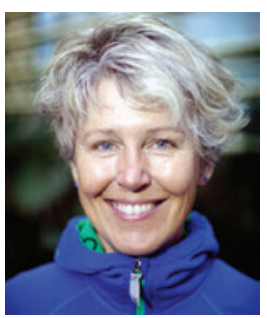

\section{Angela Wulff}

University of Gothenburg, Department of Biological and Environmental Sciences, Box 461, Gothenburg SE-405 30, Sweden

Angela Wulff is Professor in Marine Ecology, Department of Biological and Environmental Sciences, University of Gothenburg, Sweden. She holds a PhD in marine ecology/marine botany from the University of Gothenburg. After a postdoc period in Denmark, Wulff returned to Gothenburg University. Wulff has contributed to $>60$ peer-reviewed publications mainly focused on marine ecology in cold water systems, with particular emphasis on cyanobacteria and diatoms. 